\title{
BEHAVIORAL AVOIDANCE TESTS TO EVALUATE EFFECTS OF CATTLE SLURRY AND DAIRY SLUDGE APPLICATION TO SOIL ${ }^{(1)}$
}

\author{
Mariana Matos-Moreira ${ }^{(2)}$, Júlia Carina Niemeyer ${ }^{(3)}$, José \\ Paulo Sousa $^{(3)}$, Mário Cunha ${ }^{(4)} \&$ Emilio Carral ${ }^{(2)}$
}

\begin{abstract}
SUMMARY
The application of organic wastes to agricultural soils is not risk-free and can affect soil invertebrates. Ecotoxicological tests based on the behavioral avoidance of earthworms and springtails were performed to evaluate effects of different fertilization strategies on soil quality and habitat function for soil organisms. These tests were performed in soils treated with: i) slurry and chemical fertilizers, according to the conventional fertilization management of the region, ii) conventional fertilization + sludge and iii) unfertilized reference soil. Both fertilization strategies contributed to soil acidity mitigation and caused no increase in soil heavy metal content. Avoidance test results showed no negative effects of these strategies on soil organisms, compared with the reference soil. However, results of the two fertilization managements differed: Springtails did not avoid soils fertilized with dairy sludge in any of the tested combinations. Earthworms avoided soils treated with sludge as of May 2004 (DS1), when compared with conventional fertilization. Possibly, the behavioral avoidance of earthworms is more sensitive to soil properties (other than texture, organic matter and heavy metal content) than springtails
\end{abstract}

Index terms: organic waste management, ecotoxicity tests, Eisenia andrei, Folsomia candida.

\footnotetext{
(1) Received for publication in October 20, 2010 and approved in May 6, 2011.

(2) Escola Politécnica Superior, Universidade de Santiago de Compostela, Campus Universitário s/n, 27002 Lugo, Spain. E-mails: moreiramariana@portugalmail.pt; emilio.carral@usc.es

(3) IMAR-CMA, Departamento de Zoologia, Universidade de Coimbra, Largo Marquês de Pombal, 3004-517 Coimbra, Portugal. Emails: juliacarina@yahoo.com.br; jps@zoo.uc.pt

(4) Faculdade de Ciências da Universidade do Porto e Centro de Investigação em Ciências Geo-espaciais, Departamento de Matemática, Rua do Campo Alegre n 687, 4169-007 Porto, Portugal. E-mail: mcunha@mail.icav.up.pt
} 


\title{
RESUMO: TESTES DE COMPORTAMENTO DE FUGA PARA AVALIAR OS EFEITOS DA APLICACÃO DE CHORUME DE BOVINO E LODO DE INDÚSTRIA LÁCTEA NO SOLO
}

\begin{abstract}
A aplicação de resíduos orgânicos em solos agrícolas não está isenta de riscos e pode afetar os invertebrados do solo. Foram realizados testes ecotoxicológicos de comportamento de fuga usando minhocas e colêmbolos para avaliar os efeitos de diferentes estratégias de fertilização na qualidade do solo e na sua função de habitat. Esses testes foram realizados em solos que receberam: chorume e fertilizantes químicos - a estratégia de fertilização convencional na região; lodo adicionado à estratégia convencional; e solo-referência, não fertilizado. Ambas as estratégias de fertilização contribuíram para mitigar a acidez do solo e não contribuíram para aumento do teor em metais pesados do solo. Os resultados dos testes de fuga não mostraram efeitos negativos dessas estratégias nos organismos do solo, quando se comparam com os do solo-referência. Contudo, quando as duas estratégias de fertilização foram comparadas entre si, obtiveram-se resultados diferentes. Os colêmbolos não evitaram os solos fertilizados com lodo em nenhuma das combinações testadas. No entanto, as minhocas evitaram os solos que receberam lodo desde maio de 2004 (DS1). Possivelmente, o comportamento de fuga das minhocas é mais sensivel às características do solo (que não a textura, a matéria orgânica e o teor de metais pesados) do que o dos colêmbolos.
\end{abstract}

Termos de indexação: manejo de resíduos orgânicos, ensaios de ecotoxicidade, Eisenia andrei, Folsomia candida.

\section{INTRODUCTION}

Organic waste accumulation occurs over years due to the intensification of agricultural and livestock activity, industrial production and population increase in urban areas. On the other hand, agricultural intensification is gradually reducing the organic matter content in soils, thus affecting crop productivity. This is mainly a concern in Mediterranean countries, where humid winters and high summer temperatures lead to high organic matter mineralization rates (García et al., 2000). In this context, organic waste recycling in agricultural soils is one of the recommended ways to dispose of organic waste, which enriches soils with organic matter and nutrients (Petersen et al., 2003; Antolín et al., 2005). However, this practice is not risk-free, because the wastes may contain pollutants and pathogens that pose a risk to plants, animals and human health (Westerman \& Bicudo, 2005).

For this reason, legislative and normative documents, rules and codes of good agricultural practice are established and frequently revised to ensure soil and water quality as well as to protect animal and human health. Moreover, the permitted limits of organic waste disposal in soils, established based on chemical analyses and ecotoxicological biological tests are often neglected at the regulatory level.

Nevertheless, ecotoxicological tests are being used to obtain information about the effects of organic waste on soil quality and habitat of soil organisms (Crouau et al., 2002; Domene et al., 2008; Moreira et al., 2008; Natal-da-Luz et al., 2009a,b). In short-term ecotoxicological tests, behavioral avoidance tests are highly sensitive to evaluate soil contamination
(Yeardley et al., 1996; Natal-da-Luz et al., 2004; Aldaya et al., 2006; Niemeyer et al., 2006). These tests have a great potential for evaluation of the soil as habitat (Hund-Rinke \& Wiechering, 2001; HundRinke et al., 2003) and as an early screening tool in assessments of lower levels of ecological risk at contaminated sites (Loureiro et al., 2005; Natal-daLuz et al., 2004). These tests are based on the principle that organisms respond to unfavourable conditions, leaving or avoiding a contaminated soil. They constitute a quick and cost-effective means to detect low concentrations of organic contaminants (Yeardley et al., 1996).

Results of different studies using biological assays show that the suitability of a bioassay to characterize wastes depends on their origin, treatment and pollution impacts (Domene et al., 2008, Natal-da-Luz et al., 2009a,b).

The aim of this study was to perform a preliminary ecotoxicological evaluation of the soil quality degradation after slurry and dairy sludge application to agricultural soils. Behavioral avoidance tests with Eisenia andrei (Oligochaeta) and Folsomia candida (Springtails) were performed to complement soil chemical analyses.

\section{MATERIALS AND METHODS}

The experiment was conducted in fields in Vilalba (Lugo, NW Spain), with mainly humic, haplic and gleyic Umbrisols (FAO, 1998). In this region, the main agricultural activities are beef and dairy cattle and grassland management. Conventionally, chemical fertilizers and cattle slurry are widely applied after every forage cut. Application rates of chemical 
fertilisers and cattle slurry are based on the annual nutrient requirements of mixed pasture, not exceeding $170 \mathrm{~kg} \mathrm{ha}^{-1} \mathrm{yr}^{-1} \mathrm{~N}$ for organic materials.

There is a dairy processing and packaging plant in the region. Dairy industry effluents undergo a biological treatment that turn them into a semi-liquid sludge. Nowadays, this sludge is reapplied as a fertilizer to complement the conventional fertilization management. A single annual application of $80 \mathrm{~m}^{3} \mathrm{ha}^{-1}$ of dairy sludge (DS) to pastures at the beginning of the growing season is currently recommended to achieve best yields, aside from while favouring clover in competition with grass (López-Mosquera et al., 2001). The annual quantities of heavy metal applied in this sludge should never exceed the maximum levels determined by the Sludge European Directive (European Commission, 1986).

In March 2007, soil was collected from the top 15 $\mathrm{cm}$ soil from two close fields under two fertilization managements (1 and 2): one fertilized conventionally (C) (i.e., cattle slurry and chemical fertilizers) and the other including DS. At this time, a total volume of $104.18 \mathrm{~m}^{3} \mathrm{ha}^{-1}$ dairy sludge had been applied to field DS1 (distributed as $69.79 \mathrm{~m}^{3} \mathrm{ha}^{-1}$ in 2004 and $34.39 \mathrm{~m}^{3} \mathrm{ha}^{-1}$ in 2006) and $149.86 \mathrm{~m}^{3} \mathrm{ha}^{-1}$ to field DS2 (distributed as $107.32 \mathrm{~m}^{3} \mathrm{ha}^{-1}$ in 2005 and $42.54 \mathrm{~m}^{3} \mathrm{ha}^{-1}$ in 2006). The tested soils treated with cattle slurry (C) and dairy sludge (DS) had in common: a low dry matter content $\left(<20 \mathrm{~g} \mathrm{~L}^{-1}\right)$, basic $\mathrm{pH}$ (near 7) and heavy metal concentration below legal limits. The organic wastes differed mainly regarding potassium (higher in cattle slurry) and for calcium, chromium and lead (higher in DS). "Reference Soil" (R) samples were also collected from a shrub area, free of pesticide and fertilizer inputs, which represents the original landscape of the region.

In the laboratory, soils were air-dried and sieved through a $2 \mathrm{~mm}$ mesh for chemical characterisation and through a $5 \mathrm{~mm}$ mesh for the avoidance tests.

Three replicates of every soil sample were analysed for $\mathrm{pH}$ in water and in $\mathrm{KCl}$ (in a w/v suspension of 1:1 and $1: 2,5$, respectively), total $\mathrm{C}$ and $\mathrm{N}$ by combustion, extractable $\mathrm{P}$ using $\mathrm{NaHCO}_{3}$ (Olsen \& Dean, 1965), exchange cations $\left(\mathrm{Ca}^{2+}, \mathrm{Mg}^{2+}, \mathrm{Na}^{+}, \mathrm{K}^{+}\right.$, and $\left.\mathrm{Al}^{3+}\right)$ by atomic absorption spectrophotometry (Peech et al., 1947), texture by a discontinuous sedimentation method (Guitián \& Carballas, 1976), water holding capacity (ISO, 1998) and heavy metals $(\mathrm{Cr}, \mathrm{Cd}, \mathrm{Pb}$, $\mathrm{Zn}$ and $\mathrm{Ni}$ ) quantified by atomic absorption after $\mathrm{HNO}_{3}$ digestion (USEPA, 1995).

Avoidance tests were performed following the guidelines established by ISO 17512-1 for earthworms (ISO, 2008) and by ISO/CD 17512-2 for springtails (ISO, 2007). Earthworms Eisenia andrei (Oligochaeta: Lumbricidae) with well-developed clitellum and 1012 day old springtails Folsomia candida (Collembola: Isotomidae) were selected for the test. The earthworms and springtails were maintained in laboratory cultures under a photoperiod of $16 \mathrm{~h}$ light and $8 \mathrm{~h}$ dark at $20 \pm 2{ }^{\circ} \mathrm{C}$. Rectangular plastic containers (length
$20 \mathrm{~cm}$; width $12 \mathrm{~cm}$; height $5 \mathrm{~cm}$ ) and cylindrical plastic containers $(\varnothing: 7 \mathrm{~cm}$, height $6 \mathrm{~cm})$ were used, respectively, for $E$. andrei and $F$. candida. The moisture content of each soil was adjusted to $50 \%$ of the corresponding water holding capacity. Soil $\mathrm{pH}$ and moisture were quantified at the beginning and end of the tests. In both tests, containers were divided with cardboard in two sections that were filled with equal amounts of dry matter of the test soil and reference/control soil (200 g for tests with $E$. andrei and $30 \mathrm{~g}$ in tests with $F$. candida). The following combinations were tested: i) all pasture fields $(\mathrm{C} 1, \mathrm{C} 2$, DS1 and DS2) against reference soil and ii) the two fields of each set, i.e., sludge-treated fields (DS1, DS2) against conventionally fertilized fields (C1, C2) as "control soil". Five replicates per combination were performed. After soil addition the cardboard division was removed and 10 earthworms, previously washed and dried with absorbent paper, or 20 springtails, were carefully placed on the midline of each container. To keep individuals from escaping and to reduce water loss, the test containers were covered with a lid. For test containers with earthworms, a few holes were drilled in the lids to allow aeration. The tests were run for $48 \mathrm{~h}$ at $20 \pm 2{ }^{\circ} \mathrm{C}$ with a photoperiod of $16 \mathrm{~h}$ light and $8 \mathrm{~h}$ dark. At the end of the exposure time, the cardboard division was reinserted on the middle line of each container and individuals of both sections were counted. Earthworms found on the midline of the test container were counted as 0.5 individuals. For tests with springtails, the soil of one section was emptied into another container and both containers were flooded with water. Afterwards, a few drops of pen ink were added and springtails floating on the water surface were counted.

One-way Analysis of Variance (ANOVA) was used to compare the effects of different fertilization strategies on soil parameters. To identify the effects of fertilization strategies on individual sites, planned (orthogonal) comparisons were performed. The effects of the following site treatments were analyzed in three replications: within fertilized fields and between fertilized and reference soil. Avoidance test data were analysed using Fisher's exact test (Zar, 1996), which compares the observed distribution of the individuals in a specific tested combination with the theoretical distribution where a non-avoidance response is assumed as null hypothesis. For avoidance tests, a one-tailed hypothesis was applied, since only an avoidance response regarding the tested soil can be considered (Natal-da-Luz et al., 2004). In this case, the null hypothesis, rejected for $\mathrm{p} \leq 0.05$, considers that at least half of the organisms stay in the tested soil, indicating an absence of avoidance response for that soil.

\section{RESULTS AND DISCUSSION}

The differences between the tested soils were statistically significant for the analysed physical- 
chemical properties. Values for $\mathrm{pH}_{2} \mathrm{O}, \mathrm{pH} \mathrm{KCl}$, extractable $\mathrm{P}$ as well as for exchangeable $\mathrm{Ca}$ and $\mathrm{Mg}$ were higher in pasture soils (C and DS) than the reference soil (R) and they had a loamy-sand or a loamy-clay-sand texture. On the other hand, reference soil contained the highest organic matter $(\mathrm{OM})$ content, $\mathrm{C} / \mathrm{N}$ rate, exchangeable $\mathrm{Al}$ content, $\mathrm{Al}$ saturation, heavy metal concentrations (significance depending on the metal) and had a loamy texture (Table 1).

Table 1. Physical-chemical soil properties and mean comparisons between fertilization managements (mean \pm standard deviation)

\begin{tabular}{|c|c|c|c|c|c|c|c|c|c|c|c|}
\hline \multirow{2}{*}{$\begin{array}{l}\text { Physical- } \\
\text { chemical } \\
\text { property }\end{array}$} & \multicolumn{11}{|c|}{ Sampled field } \\
\hline & \multicolumn{2}{|c|}{ C1 } & \multicolumn{2}{|r|}{ DS1 } & \multicolumn{3}{|c|}{$\mathrm{C} 2$} & \multicolumn{2}{|c|}{ DS2 } & \multicolumn{2}{|r|}{$\mathbf{R}$} \\
\hline $\mathrm{pH} \mathrm{H} \mathrm{H}_{2} \mathrm{O}$ & \multicolumn{2}{|c|}{$6.18 \pm 0.01$} & \multicolumn{2}{|c|}{$5.73 \pm 0.01$} & \multicolumn{3}{|c|}{$5.77 \pm 0.03$} & \multicolumn{2}{|c|}{$5.86 \pm 0.01$} & \multicolumn{2}{|c|}{$5.08 \pm 0.02$} \\
\hline $\mathrm{pH} \mathrm{KCl}$ & \multicolumn{2}{|c|}{$5.20 \pm 0.01$} & \multicolumn{2}{|c|}{$4.50 \pm 0.01$} & \multicolumn{2}{|c|}{$4.66 \pm 0.02$} & \multicolumn{3}{|c|}{$4.78 \pm 0.01$} & \multicolumn{2}{|c|}{$4.08 \pm 0.01$} \\
\hline $\mathrm{OM}(\%)$ & \multicolumn{2}{|c|}{$12.20 \pm 0.66$} & \multicolumn{2}{|c|}{$10.16 \pm 0.36$} & \multicolumn{2}{|c|}{$11.25 \pm 0.26$} & \multicolumn{3}{|c|}{$11.23 \pm 0.17$} & 13.3 & $9 \pm 0.17$ \\
\hline N (\%) & $0.56 \pm$ & & & $49 \pm 0.02$ & & $53 \pm 0.02$ & & $0.57 \pm 0$ & & & $1 \pm 0.00$ \\
\hline $\mathrm{C} / \mathrm{N}$ & $12.52 \pm$ & & & $99 \pm 0.01$ & & $37 \pm 0.09$ & & $11.51 \pm 0$ & & 15.2 & $4 \pm 0.13$ \\
\hline $\mathrm{P}\left(\mathrm{mg} \mathrm{kg}^{-1}\right)$ & $22.19 \pm$ & & & $55 \pm 0.46$ & & $47 \pm 0.52$ & & $23.76 \pm 3$ & & & $8 \pm 0.20$ \\
\hline $\mathrm{Ca}^{2+}\left(\mathrm{cmol}_{\mathrm{c}} \mathrm{kg}^{-1}\right)$ & $7.01 \pm$ & & & $02 \pm 0.25$ & & $29 \pm 0.19$ & & $3.59 \pm 0$ & & & $8 \pm 0.05$ \\
\hline $\mathrm{Mg}^{2+}\left(\mathrm{cmol}_{\mathrm{c}} \mathrm{kg}^{-1}\right)$ & $0.87 \pm$ & & & $65 \pm 0.05$ & & $74 \pm 0.07$ & & $0.91 \pm 0$ & & & $0 \pm 0.04$ \\
\hline $\mathrm{Na}^{+}\left(\mathrm{cmol}_{\mathrm{c}} \mathrm{kg}^{-1}\right)$ & $0.29 \pm$ & & & $30 \pm 0.03$ & & $30 \pm 0.03$ & & $0.33 \pm 0$ & & & $0 \pm 0.01$ \\
\hline $\mathrm{K}^{+}\left(\mathrm{cmol}_{\mathrm{c}} \mathrm{kg}^{-1}\right)$ & $0.54 \pm$ & & & $26 \pm 0.02$ & & $59 \pm 0.18$ & & $0.27 \pm 0$ & & & $0 \pm 0.04$ \\
\hline $\mathrm{Al}^{3+}\left(\mathrm{cmol}_{\mathrm{c}} \mathrm{kg}^{-1}\right)$ & $0.18 \pm$ & & & $72 \pm 0.03$ & & $93 \pm 0.14$ & & $0.70 \pm 0$ & & & $5 \pm 0.06$ \\
\hline $\mathrm{Al}$ sat. $(\%)$ & $2.06 \pm$ & & & $54 \pm 0.97$ & & $92 \pm 0.78$ & & $12.04 \pm 0$ & & 45.5 & $3 \pm 1.32$ \\
\hline CEC & $8.89 \pm$ & & & $95 \pm 0.32$ & & $85 \pm 0.59$ & & $5.80 \pm 0$ & & & $2 \pm 0.16$ \\
\hline $\mathrm{Cr}\left(\mathrm{mg} \mathrm{kg}^{-1}\right)$ & $8.43 \pm$ & & & $40 \pm 1.10$ & & $58 \pm 0.08$ & & $12.53 \pm 0$ & & 19.3 & $0 \pm 0.55$ \\
\hline $\mathrm{Cu}\left(\mathrm{mg} \mathrm{kg}^{-1}\right)$ & $8.45 \pm$ & & & $98 \pm 1.03$ & & $45 \pm 0.00$ & & $11.48 \pm 0$ & & 21.6 & $3 \pm 0.27$ \\
\hline $\mathrm{Pb}\left(\mathrm{mg} \mathrm{kg}^{-1}\right)$ & $0.50 \pm$ & & & $75 \pm 0.25$ & & $25 \pm 0.25$ & & $5.50 \pm 1$ & & & $0 \pm 0.50$ \\
\hline $\mathrm{Zn}\left(\mathrm{mg} \mathrm{kg}^{-1}\right)$ & $23.81 \pm$ & & & $84 \pm 1.00$ & & $70 \pm 0.28$ & & $29.00 \pm 0$ & & 33.0 & $9 \pm 0.45$ \\
\hline $\mathrm{Ni}\left(\mathrm{mg} \mathrm{kg}^{-1}\right)$ & $0.00 \pm$ & & & $50 \pm 0.40$ & & $00 \pm 0.05$ & & $0.78 \pm 0$ & & & $5 \pm 1.15$ \\
\hline Sand $(\%)$ & 68.7 & & & 0.57 & & 57.60 & & 57.65 & & & 8.77 \\
\hline Silt (\%) & 16.9 & & & 20.85 & & 22.75 & & 22.30 & & & 7.77 \\
\hline Clay (\%) & 14.3 & & & 18.58 & & 19.64 & & 20.05 & & & 3.46 \\
\hline Texture & Loam-sa & & & m-sandy & & am-sandy & & Loam-clay & andy & & amy \\
\hline & & & & Significa & ce of Mea & n Planne & ed Compar & hrisons (a & & & \\
\hline & C-R & DS-R & C-DS & C1-DS1 & C2-DS2 & C1-C2 & DS1-DS2 & C1-R & C2-R & DS1-R & DS2-R \\
\hline $\mathrm{pH} \mathrm{H} \mathrm{H}_{2} \mathrm{O}$ & $* * *$ & $* * *$ & $\mathrm{~ns}$ & $* * *$ & $* * *$ & $* * *$ & $* * *$ & $* * *$ & $* * *$ & $* * *$ & $* * *$ \\
\hline $\mathrm{pH} \mathrm{KCl}$ & $* * *$ & $* *$ & $*$ & $* * *$ & $* * *$ & $* * *$ & $* * *$ & $* * *$ & $* * *$ & $* * *$ & $* * *$ \\
\hline $\mathrm{OM}(\%)$ & $* *$ & $* * *$ & * & $* * *$ & ns & $* *$ & $* *$ & $* *$ & $* * *$ & $* * *$ & $* * *$ \\
\hline N (\%) & $\mathrm{ns}$ & $\mathrm{ns}$ & $\mathrm{ns}$ & $* * *$ & * & * & $* * *$ & $* *$ & $\mathrm{~ns}$ & $\mathrm{~ns}$ & $* *$ \\
\hline $\mathrm{C} / \mathrm{N}$ & $* * *$ & $* * *$ & $* * *$ & $* * *$ & $* * *$ & * & $* * *$ & $* * *$ & $* * *$ & $* * *$ & $* * *$ \\
\hline $\mathrm{P}\left(\mathrm{mg} \mathrm{kg}^{-1}\right)$ & $* * *$ & * & $\mathrm{ns}$ & $* * *$ & $\mathrm{~ns}$ & $\mathrm{~ns}$ & $* * *$ & $* * *$ & $* * *$ & * & $* * *$ \\
\hline $\mathrm{Ca}^{2+}$ & $* * *$ & * & * & $* * *$ & * & $* * *$ & $* * *$ & $* * *$ & $* * *$ & $* * *$ & $* * *$ \\
\hline $\mathrm{Mg}^{2+}$ & $* *$ & $* *$ & $\mathrm{~ns}$ & $* * *$ & $* * *$ & $* *$ & $* * *$ & $* * *$ & $* * *$ & $* *$ & $* * *$ \\
\hline $\mathrm{Na}^{+}\left(\mathrm{cmol}_{\mathrm{c}} \mathrm{kg}^{-1}\right)$ & $\mathrm{ns}$ & $\mathrm{ns}$ & $\mathrm{ns}$ & $\mathrm{ns}$ & $\mathrm{ns}$ & $\mathrm{ns}$ & $\mathrm{ns}$ & $\mathrm{ns}$ & $\mathrm{ns}$ & $\mathrm{ns}$ & $\mathrm{ns}$ \\
\hline $\mathrm{K}^{+}\left(\mathrm{cmol}_{\mathrm{c}} \mathrm{kg}^{-1}\right)$ & $\mathrm{ns}$ & $* * *$ & $* * *$ & $* *$ & $* * *$ & $\mathrm{~ns}$ & $\mathrm{~ns}$ & $\mathrm{~ns}$ & $\mathrm{~ns}$ & $* *$ & $* *$ \\
\hline $\mathrm{Al}^{3+}\left(\mathrm{cmol}_{\mathrm{c}} \mathrm{kg}^{-1}\right)$ & $* * *$ & $* * *$ & $\mathrm{~ns}$ & $* * *$ & $* *$ & $* * *$ & $\mathrm{~ns}$ & $* * *$ & $* * *$ & $* * *$ & $* * *$ \\
\hline $\mathrm{Al}$ sat. $(\%)$ & $* * *$ & $* * *$ & $\mathrm{~ns}$ & $* * *$ & $* * *$ & $* * *$ & $* *$ & $* * *$ & $* * *$ & $* * *$ & $* * *$ \\
\hline CEC & $* * *$ & ns & $*$ & $* * *$ & $\mathrm{~ns}$ & $* * *$ & $* *$ & $* * *$ & $* * *$ & $* * *$ & $* * *$ \\
\hline $\mathrm{Cr}\left(\mathrm{mg} \mathrm{kg}^{-1}\right)$ & $* * *$ & * & * & $* * *$ & * & $* * *$ & $* * *$ & $* * *$ & $* * *$ & $* * *$ & $* * *$ \\
\hline $\mathrm{Cu}\left(\mathrm{mg} \mathrm{kg}^{-1}\right)$ & $* * *$ & $* * *$ & $* *$ & $* * *$ & $\mathrm{~ns}$ & $* * *$ & $* * *$ & $* * *$ & $* * *$ & $* * *$ & $* * *$ \\
\hline $\mathrm{Pb}\left(\mathrm{mg} \mathrm{kg}^{-1}\right)$ & $\mathrm{ns}$ & $\mathrm{ns}$ & $\mathrm{ns}$ & $* * *$ & $\mathrm{~ns}$ & $* * *$ & $* * *$ & $* * *$ & * & $* * *$ & $\mathrm{~ns}$ \\
\hline $\mathrm{Zn}\left(\mathrm{mg} \mathrm{kg}^{-1}\right)$ & $* *$ & $\mathrm{~ns}$ & $\mathrm{~ns}$ & $* * *$ & $* *$ & $* * *$ & $* * *$ & $* * *$ & $* * *$ & * & $* * *$ \\
\hline $\mathrm{Ni}\left(\mathrm{mg} \mathrm{kg}^{-1}\right)$ & $* * *$ & $* * *$ & $\mathrm{~ns}$ & $* * *$ & * & $* *$ & $* * *$ & $* * *$ & $* * *$ & $* * *$ & $* * *$ \\
\hline
\end{tabular}

C1 and C2: fields of each set treated with conventional fertilization. DS1and DS2: Fields of each set treated with sludge as of May 2004 (DS1) or May 2005 (DS2). R: reference soil. (a) Planned contrasts (orthogonal): 1) compare means recorded in each fertilization management and with reference soil (first three columns), 2).compare means in each field, strategies and soil reference. Significance level: ${ }^{*}: p \leq 0.05, * *: p \leq 0.010, * * * * p \leq 0.001$ 
The acidic properties of the reference soil are representative of the soils of this region. Conventional fertilization and/or sludge disposal has contributed to soil acidity mitigation, increasing $\mathrm{pH}$ and reducing $\mathrm{Al}$ saturation (Table 1). Many studies showed that organic residues contribute to reduce problems with soil acidification, since they reduce $\mathrm{Al}$ toxicity in addition to contributing to $\mathrm{OM}$ and nutrient enrichment (Mokolobate \& Haynes, 2002). In addition, the low concentrations of heavy metals found in the DS used in this study did not cause an increase in soil concentration, compared with reference soil (Table 1). Nowadays, the production of sludge and other organic wastes from varied sources is on the rise. Sludge from dairy industries is considered to contain lower levels of heavy metals and organic pollutants than sewage sludge from other sources (Bertsch, 2000; López-Mosquera et al., 2005). For this reason, some national programmes encourage a different political approach for this sludge (Issa et al., 2007).

When the pasture soils under different fertilization managements were compared, the values of $\mathrm{pH} \mathrm{KCl}$, $\mathrm{OM}, \mathrm{C} / \mathrm{N}$ rate and exchangeable $\mathrm{Ca}$ and $\mathrm{K}$ were highest in conventionally fertilized (C) fields. On the contrary, values of $\mathrm{Cr}$ and $\mathrm{Cu}$ were highest in fields fertilized with DS (mean comparisons in Table 1). Moreover, differences were detected among studied soils, even when the same OM source was used (C1C2 and DS1-DS2) (Table 1). Dairy sludge was applied to Field DS2 later than to DS1 (see Materials and Methods), but total amounts applied to DS2 were higher, contributing to better soil properties in this soil (Table 1).

Results of the avoidance tests are shown in figure 1. No mortality was observed in any test container.

When the sown pasture soils (C and DS) were compared with reference soil (R), no behavioral avoidance response by either earthworms or springtails was found (Figure 1). This could be expected due to the low heavy metal contents in the tested soils (Table 1). Moreira et al. (2008), evaluating the loss of habitat function after organic waste disposal, also observed no avoidance response of these organisms in any treatment applied. In that study, earthworms preferred soils fertilized with sludge or compost to the artificial OECD's soil (Organization for Economic Cooperation and Development). The more favourable properties to organism development observed in the tested soils, e.g., the higher $\mathrm{pH}$ values and nutrient concentrations (mainly P and Ca) (Edwards \& Bohlen, 1996), could also explain the no-avoidance response of these organisms. However, despite the no-avoidance response of earthworms and springtails to the pasture soils, chronic effects (eg. on reproduction, bioaccumulation) after longer exposure periods cannot be ruled out.

In a comparison of the different fertilization strategies, different results were observed in the tests with earthworms, depending on the tested combination (Figure 1). Comparing C2 (with conventional fertilization) and DS2 fields (with sludge application as of May 2005), earthworms did not avoid soils where
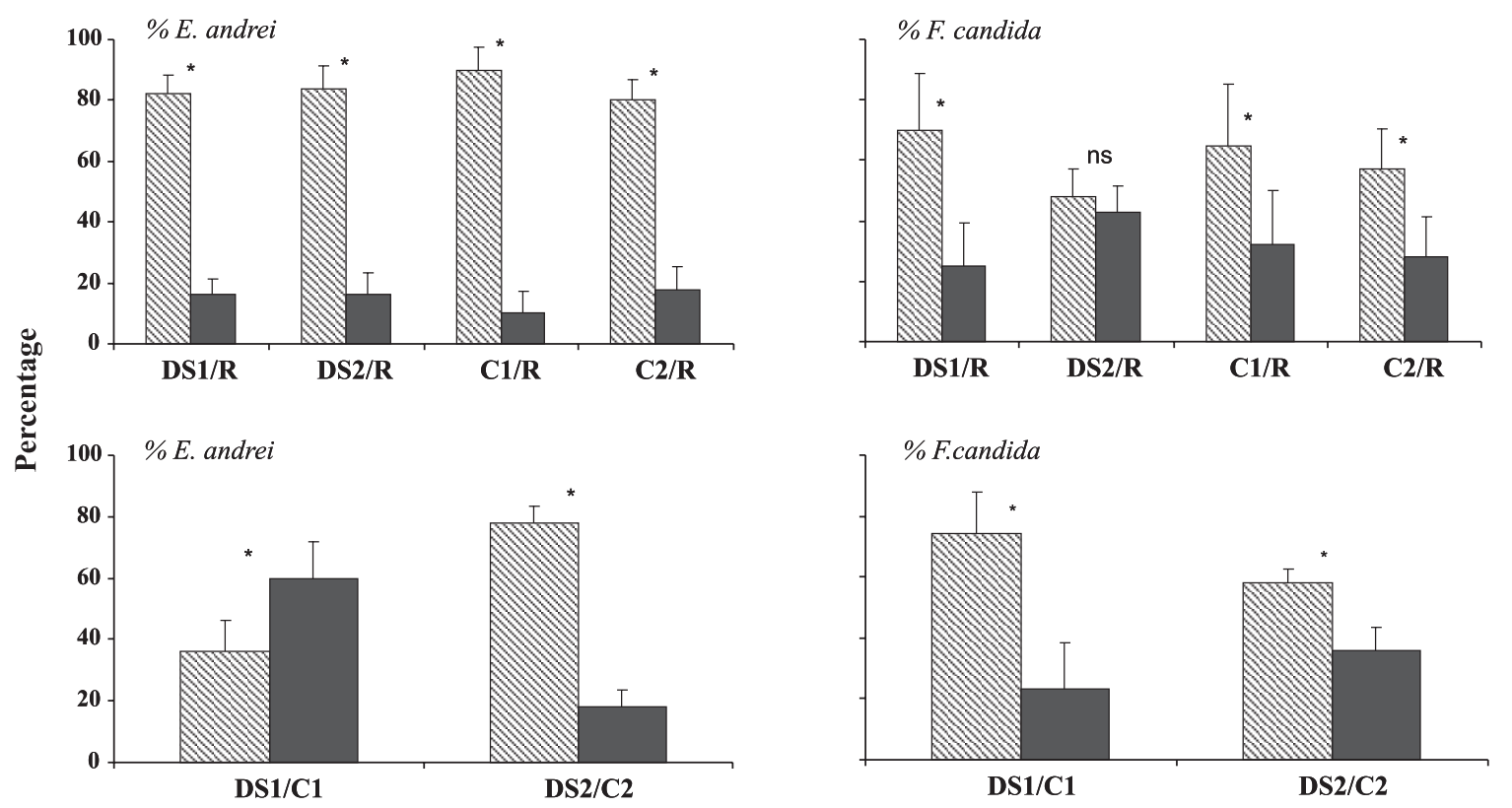

Figure 1. Avoidance response of earthworms (Eisenia andrei) and springtails (Folsomia candida) in different tested soils. C1 and C2: fields treated with conventional fertilization. DS1, DS2: Fields treated with sludge as of May 2004 (DS1), May 2005 (DS2). R: reference soil. Values are the average percentage of organisms found on control or tested sides. Vertical lines represent standard deviation. *: significantly higher percentage of organisms on the control side than on the tested side $(p<0.05)$. 
sludge had been applied (Figure 1). On the other hand, earthworms avoided sludge -treated soils, when $\mathrm{C} 1$ (with conventional fertilization) and DS1 (with sludge application as of May 2004) fields were compared (Figure 1). These different responses could be related with differences in soil properties. Natal-da-Luz et al. (2008), testing combinations of artificial soils with different $\mathrm{OM}$ content and texture, showed that the avoidance response of soil organisms could be influenced by these properties. According to these authors, earthworms preferred soils with higher OM content and coarse texture; this response is stronger if the difference between soils is high, regardless of the soil contamination level. In this case, both soils (C1 and DS1) had the same texture type, but all chemical properties analysed (except $\mathrm{Na}$ ) were significantly different (Table 1). Favourable properties of soil $\mathrm{C} 1$ could have influenced the earthworm behaviour. The positive effect of suitable $\mathrm{Ca}$ and $\mathrm{pH}$ values for earthworms is well-known (Edwards \& Bohlen, 1996). However, little information is available in literature concerning other soil chemical parameters. Some authors described toxic effects of $\mathrm{Al}$ to these organisms (Philips \& Bolger 1998; van Gestel \& Hoogerwerf, 2001), but to date this soil property is not taken into account in behavioural avoidance tests. In this study, comparing both soils (DS1 and C1) high significant differences ( $p \leq 0.001)$ were observed for Al saturation (Table 3) and earthworms preferred soils with the lowest values (DS1) (Figure 1). Also, some soil propoerties not analysed in this study may be involved.

On the other hand, springtails did not avoid soils fertilized with DS in any of the tested combinations (Figure 1). Hence, soils fertilized with complementary DS did not affect the soil habitat function of these invertebrates. The results of other studies involving the ecotoxicological assessment of organic wastes, including sludge from agro-industries, using $F$. candida, were similar (Natal-da-Luz et al., 2009a). Springtails were less influenced by soil chemical parameters than earthworms. This is in agreement with Natal-da-Luz et al. (2008), who considered that springtails were better suited for avoidance tests performed in natural soils with different chemical properties.

\section{CONCLUSIONS}

1. Both fertilization strategies, conventional or with dairy sludge, contributed to soil acidity mitigation and caused no increase in soil heavy metal content.

2. Results of avoidance tests showed no negative effects of conventional or dairy sludge fertilization on soil organisms, compared with the reference soil.

3. Different results were obtained for earthworm behaviour in response to fertilization strategies: soils where sludge had been applied as of May 2005 (DS2) were not avoided, but avoidance was observed in sludge-treated soils as of May 2004 (DS1), compared to conventional fertilization. A possible explanation involves soil properties, other than texture, organic matter and heavy metal content.

4. Springtails were less influenced by soil chemical properties than earthworms and did not avoid soils fertilized with dairy sludge in any of the tested combinations.

\section{ACKNOWLEDGEMENTS}

This study was supported by Fundação para a Ciência e a Tecnologia (Portugal), through a PhD grant to Mariana Matos-Moreira (SFRH/BD18486/ 2004) and to Júlia Niemeyer (SFRH/BD/28796/2006). In memory of Margarida Maria Matos Reis. The authors would like to thank Dr. Tiago Natal da Luz for his contribution for improve the manuscript, and also the two anonymous reviewers, for their comments and suggestions.

\section{LITERATURE CITED}

ALDAYA, M.M.; LORS, C.; SALMON, S. \& PONGE, J.-F. Avoidance bio-assays may help to test the ecological significance of soil pollution. Environ Pollut., 140:173180, 2006.

ANTOLÍN, M.C.; PASCUAL, I.; GARCÍA, C.; POLO, A. \& SÁNCHEZ-DÍAZ, M. Growth, yield and solute content of barley in soils treated with sewage sludge under semiarid Mediterranean conditions. Field Crops Res., 94:224-237, 2005.

CROUAU, Y.; GISCLARD, C. \& PEROTTI, P. The use of Folsomia candida (Collembola, Isotomidae) in bioassays of waste. Appl. Soil Ecol., 19:65-70, 2002.

DOMENE, X.; RAMIREZ, W.; MATTANA, S.; ALCANIZ, J.M. \& ANDRES, P. Ecological risk assessment of organic waste amendments using the species sensitivity distribution from a soil organisms test battery. Environ Pollut., 155:227-236, 2008.

EDWARDS, C.A. \& BOHLEN, P.J. Biology and ecology of earthworms. 3.ed. London, Chapman \& Hall, 1996. 426p.

EUROPEAN COMMISSION. Council Directive 86/278/EEC of 12 June 1986 on the protection of environment, and in particular of the soil, when sewage sludge is used in agriculture. Official J. L., 181:6-12, 1986.

FAO. World reference base for soil resources. Rome, 1998. (World Soil Resources Reports, 84)

GARCÍA, C.; HERNÁNDEZ, T.; PASCUAL, J.A.; MORENO, J.L. \& ROS, M. Microbial activity in soils of SE Spain exposed to degradation and desertification processes: Strategies for their rehabilitation. In: GARCÍA, C. \& HERNÁNDEZ, T., eds. Research and perspectives of soil enzymology in Spain. Murcia, CEBAS, CSIC, 2000. p.93-143. 
GUITIÁN, F. \& CARBALLAS, T. Técnicas de análisis de suelos. 2.ed. Santiago de Compostela, Pico-Sacro, 1976. 288p.

HUND-RINKE, K.; ACHAZI, R.; ROMBKE, J. \& WARNECKE, D. Avoidance test with Eisenia fetida as indicator for the habitat function of soils: Results of a laboratory comparison test. J. Soils Sedim., 1:7-12, 2003.

HUND-RINKE, K. \& WIECHERING, H. Earthworm avoidance test for soil assessments. An alternative for acute and reproduction tests. J. Soils Sedim., 1:15-20, 2001.

ISO. Soil quality- Determination of the water-retention characteristic. Laboratory methods. ISO 11274. Geneve, International Organization for Standardization, 1998.

ISO. Soil quality - Avoidance test for determining the quality of soils and effects of chemicals on behaviour- Part 2: Test with collembolans (Folsomia candida). ISO/CD 17512-2. Genève, International Organization for Standardization, 2007.

ISO. Soil quality- Avoidance test for determining the quality of soils and effects of chemicals on behaviour - Part 1 : Test with earthworms (Eisenia fetida and Eisenia andrei). ISO 17512-1. Genève, International Organization for Standardization, 2008.

ISSA, J.; MEEHAN, B.; WILKINSON, K. \& SURAPENENI, A. The sustainable application of dairy factory sludges/wastes on agricultural land closing the loop- an holistic approach to the management of dairy processor waste streams. Melbourne, RMIT University, 2007. p.36. Access under: $<\mathrm{http}$ :// diaa.asn.au/imagebank/Doc/ Closing\%20the\%20Loop/Technical\%20Reports/Sludge/ $2007 \% 20 \mathrm{Final} \% 20 \mathrm{Report} \% 20 \mathrm{Sustainable \%}$ 20 application $\% 20$ of $\% 20$ dairy $\% 20$ sludgewas . pdf> Access date: Jan. 22, 2008.

LÓPEZ-MOSQUERA, M.E.; ALONSO, X.A. \& SAINZ, M.J. Short-term effects of soil amendment with dairy sludge on yield, botanical composition, mineral nutrition and arbuscular mycorrhization in a mixed sward. Pastos, 29:231-243, 2001.

LÓPEZ-MOSQUERA, M.E.; BARROS, R.; SAINZ, M.J.; CARRAL, E. \& SEOANE, S. Metal concentrations in agricultural and forestry soils in northwest Spain: Implications for disposal of organic wastes on acid soils. Soil Use Manag., 21:298-305, 2005.

LOUREIRO, S.; SOARES, A.M.V.M. \& NOGUEIRA, A.J.A. Terrestrial avoidance behaviour tests as screening tool to assess soil contamination. Environ Pollut., 138:121$131,2005$.

MOKOLOBATE, M.S. \& HAYNES, R.J. Comparative liming effect of four organic residues applied to an acid soil. Biol. Fert. Soils, 35:79-85, 2002.

MOREIRA, R.; SOUSA, J.P. \& CANHOTO, C. Biological testing of a digested sewage sludge and derived composts. Biores. Technol., 99:8382-8389, 2008.

NATAL-DA-LUZ, T.; RIBEIRO, R. \& SOUSA, J.P. Avoidance tests with collembola and earthworms as early screening tools for site-specific assessment of polluted soils. Environ. Toxicol. Chem., 23:2188-2193, 2004.
NATAL-DA-LUZ, T.; ROMBKE, J. \& SOUSA, J.P. Avoidance tests in site-specific risk assessment-influence of soil properties on the avoidance response of collembola and earthworms. Environ. Toxicol. Chem., 27:1112-1117, 2008.

NATAL-DA-LUZ, T.; TIDONA, S.; JESUS, B.; MORAIS, P.V. \& SOUSA, J.P. The use of sewage sludge as soil amendment. The need for an ecotoxicological evaluation. J. Soils Sedim., 9:246-260, 2009a.

NATAL-DA-LUZ, T.; TIDONA, S.; van GESTEL, C.A.M.; MORAIS, P.V. \& SOUSA, J.P. The use of Collembola avoidance tests to characterize sewage sludges as soil amendments. Chemosphere, 77:1526-1533, 2009b.

NIEMEYER, J.C.; DOS-SANTOS, V.C.; RODRIGUES, J.M.L. \& DA-SILVA, E.M. Comportamento de Cubaris murina Brandt (Crustacea: Isopoda) em solo com glifosato: Testes de fuga em laboratório. J. Braz. Soc. Ecotoxicol., 1:1-4, 2006.

OLSEN, R.A. \& DEAN, L.A. Phosphorous. In: BLACK, C.A., ed. Methods of soil science. Madison, America Society of Agronomy, 1965. p.403-430.

PEECH, M.; ALEXANDER, L.T.; DEAN, L. \& REED, J.F. Methods of soil analysis for soil fertility investigations. Washington DC, US Government Printing Office, 1947. 25p. (USDA Circular, 757)

PETERSEN, S.O.; HENRIKSEN, K.; MORTENSEN, G.K.; KROGH, P.H.; BRANDT, K.K.; SøRENSEN, J.; MADSEN, T.; PETERSEN, J. \& GRØN, C. Recycling of sewage sludge and household compost to arable land: Fate and effects of organic contaminants, and impact on soil fertility. Soil Tillage Res., 72:139-152, 2003.

PHILLIPS, D.R. \& BOLGER, T. Sublethal toxic effects of aluminium on the earthworm Eisenia fetida. Pedobiologia, 42:125-130, 1998.

USEPA. Method 3051: Microwave assisted acid digestion of sediments, sludges, soils, and oils. Test methods for evaluating solid waste. Washington DC, US Environmental Protection Agency, 1995.

van GESTEL, C.A.M. \& HOOGERWERF, G. Influence of soil $\mathrm{pH}$ on the toxicity of aluminium for Eisenia andrei (Oligochaeta: Lumbricidae) in an artificial soil substrate. Pedobiologia, 45:385-395, 2001.

WESTERMAN, P.W. \& BICUDO, J.R. Management considerations for organic waste use in agriculture. Biores. Technol., 96:215-221, 2005.

YEARDLEY, R.B.; LAZORCHAK, J.M. \& GAST, L.C. The potential of an earthworm avoidance test for evaluation of hazardous waste sites. Environ. Toxicol. Chem., 15:1532-1537, 1996.

ZAR, J. Biostatistical analysis. 3.ed. Upper Saddle River, New Jersey, Prentice-Hall, 1996. 918p. 
